\title{
ІХТІОЛОГІЯ
}

УДК 597.541

doi:10.25128/2078-2357.19.1.13

\section{К.М. ГЕЙНА}

Інститут рибного господарства НААН України

вул. Обухівська, 135, Київ, 03164

e-mail: geina_k@ukr.net

\section{МОРФО-БІОЛОГІЧНА ХАРАКТЕРИСТИКА ПУЗАНКА ДНІПРОВСЬКО-БУЗЬКОЇ ГИРЛОВОЇ СИСТЕМИ}

В статті представлена інформація щодо сучасного біологічного стану промислового стада пузанка (Alosa caspia tanaica, G., 1901) Дніпровсько-Бузької гирлової системи. Проаналізовані меристичні, пластичні ознаки, визначені статевий диморфізм та динаміка структурних характеристик стада.

Ключові слова: Дніпровсько-Бузька гирлова система, пузанок, пластичні, меристичні ознаки, структура стада

Вступ. Зарегулювання стоку Дніпра призвело до змін водного режиму Дніпровсько-Бузької гирлової системи, що негативно відобразилося на умовах існування гідробіонтів у тому числі і риб. В результаті відбувся структурний перерозподіл промислових уловів. Якщо до побудови Каховської ГЕС частка напівпрохідних та місцевих риб у загальному вилові в пониззі Дніпра перевищувала $80 \%$, то в умовах сьогодення найбільшу питому вагу має малоцінна тюлька біля $80 \%$ [1].

На фоні погіршання якісного складу іхтіофауни в пониззі Дніпра виникла нагальна необхідність пошуку нових резервів для рибного господарства регіону, зокрема цінних у харчовому відношенні об’ єктів промислу, запаси яких дозволяють збільшити обсяги вилову.

Одним 3 таких об'єктів є чорноморсько-азовський пузанок Alosa caspia tanaica (Grimm, 1901), який заходить з Чорного моря у водойми Дніпровсько-Бузької гирлової системи для відтворення та нагулу. Відповідними науковими напрацюваннями встановлено, що він $\epsilon$ відособленою частиною стада дунайського пузанка, який мешкає у північно-західній частині Чорного моря [2].

Біологію пузанка Дніпровсько-Бузького лиману вивчали різні автори [3-6]. Вони вказують на терміни нерестової міграції пузанка, описують місця відтворення, їх характеристику, температурні межі нересту, лінійно-вагові характеристики, статеве співвідношення, плодючість та інш. Відомості щодо розмірно-вікового складу у певні роки були досить протиречними. В той же час біологія та умови відтворення пузанка у водоймах дельти Дніпра практично не вивчалися.

Дослідженнями було встановлено, що в межах Дніпровсько-Бузької гирлової системи відмічається наявність двох форм пузанків, так зване «річкове стадо» та «лиманське стадо». Відрізняються вони за деякими меристичними та пластичними ознаками, а також певними особливостями біології. У подальших дослідженнях різницю за деякими ознаками між зрівнюваними групами пузанків фахівці пояснюють більшою пластичністю оселедцевих i 
об’єднують вищевказані форми в одне стадо пузанка Дніпровсько-Бузької естуарної системи [7-9].

Всі означені вище напрацювання відносилися до 50-60-х років минулого століття. Сучасна інформація щодо біологічних характеристик пузанка Дніпровсько-Бузької гирлової системи у доступних літературних джерелах $є$ обмеженою, що і спонукало до проведення відповідного обсягу дослідницьких робіт на сучасному етапі.

\section{Матеріал і методи досліджень}

В роботі використано іхтіологічний матеріал, яки збирався під час роботи контрольноспостережних пунктів Інституту рибного господарства НААН України, які щорічно функціонували на акваторії Дніпровсько-Бузької гирлової системи. Польова та камеральна обробка зразків виконувалася у відповідності до загальновизнаних в практиці іхтіологічних досліджень методик та керівництв [10-13]. Математичний аналіз отриманих результатів здійснено за [14-15].

\section{Результати досліджень та їх обговорення}

У пузанка, який мігрує для відтворення у Дніпровсько-Бузьку гирлову систему меристичні

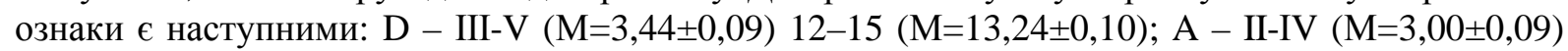

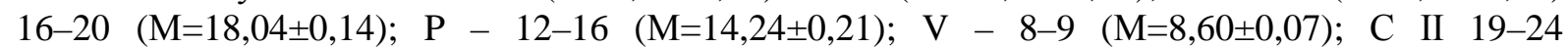
( $\mathrm{M}=21,82 \pm 0,16)$; черевних шипиків 30-34 (M=31,74 $\pm 0,17)$.

Тіло видовжене, відносно невисоке ( $\mathrm{H}=22,64 \pm 0,20 \%$; lim=19,86-25,33\%), дещо сплощене

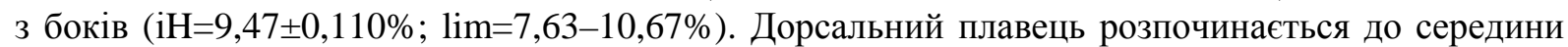
повздовжньої осі тіла - $\mathrm{aD}=45,82 \pm 0,26 \%$ і не заходить за неї навіть при максимальних відхиленнях ознаки - lim=19,86-25,33\%.

Анальний плавець 3 довжиною $1 \mathrm{~A}=15,42 \pm 0,18 \%$ та висотою $\mathrm{hA}=5,71 \pm 0,14 \%$ розташовується на відстані, яка змінюється в межах від 66,89 до 74,50\% довжини тіла (Lc), а в середньому становить $69,81 \pm 0,30 \%$.

Черевні плавці розміщені дещо позаду від вертикалі початку основи спинного плавця $\mathrm{aV}=48,36 \pm 0,20 \% \quad(\lim =46,28-51,68 \%)$. Відстань до анального плавця становить $\mathrm{VA}=22,61 \pm 0,17 \%$ (lim=19,85-24,39\%), а до грудних $-\mathrm{PV}=23,63 \pm 0,20 \%$ (lim=20,61-26,85\%). Грудні плавці є набагато довшими за черевні - відповідно $1 \mathrm{P}=15,44 \pm 0,20 \%$ та $1 \mathrm{~V}=9,87 \pm 0,10 \%$ при варіабельності ознак $\mathrm{Cv}=5,80-7,27 \%$.

При довжині голови, яка дорівнює $25,69 \pm 0,23 \%$, висота є досить мінливою ознакою і варіює в межах від 51,35 до $78,38 \%$, в середньому становить $68,68 \pm 1,17 \%$. Лоб не широкий $\mathrm{lo}=17,39 \pm 0,26 \%$ (lim=13,89-20,59\%), очі великі $\mathrm{do}=22,59 \pm 0,30 \%$ (lim=18,92-25,71\%). Рило $\epsilon$ коротшим за довжину позаокового простору $-\mathrm{ar}=28,07 \pm 0,23 \%$ та pc $=49,21 \pm 0,96 \%$. При цьому мінливість $(\mathrm{Cv})$ становила відповідно 5,84 та $13,72 \%$.

Варіабельність пластичних ознак пузанка обумовлювалася головним чином присутністю у стаді статевого диморфізму. У розміщенні анального плавця достовірної різниці не зафіксовано, проте у самиць він набагато нижчий, ніж у самців - Mdif становить 10,80 (табл. 1).

Спинний плавець самців $\epsilon$ більш зміщеним у каудальному напрямку $(\mathrm{Mdif}=8,38)$. Також він коротший $(\mathrm{Mdif}=5,55)$ та нижчий $(\mathrm{Mdif}=3,36)$. Помічена також достовірна різниця у пектровентральній відстані (Mdif=4,29), довжині грудних плавців (Mdif=3,05) та хвостового стебла (Mdif=9,78).

Аналіз пластичних ознак відділу голови у пузанків вказав на те, що за довжиною голови достовірної різниці не виявлено, проте у співвідношенні інших ознак існують відмінності за більшістю ознак. Голова у самців $є$ набагато вищою (Mdif $=11,25)$. Також у них більший діаметр ока (Mdif=4,66), довжина рила (Mdif=3,15) та позаоокова відстань (Mdif=6,14). При цьому за шириною лоба достовірної різниці між самцями та самицями не виявлено.

Динаміка середнього віку пузанка вказує на поступове відновлення чисельності стада. Протягом 2006-2015 рр. він збільшився від 2,40 р. до 2,63-2,68 р. (рис. 1). 
Аналіз статевого диморфізму пузанка Дніпровсько-Бузької гирлової системи

\begin{tabular}{|c|c|c|c|c|c|}
\hline \multirow{2}{*}{ Ознака } & \multicolumn{2}{|c|}{ Самиці, n=25 } & \multicolumn{2}{|c|}{ Самці, n=25 } & \multirow{2}{*}{ Mdif } \\
\hline & $\mathrm{M}$ & $\pm \mathrm{m}$ & $\mathrm{M}$ & $\pm \mathrm{m}$ & \\
\hline Lc, cM & 13,78 & 0,29 & 14,31 & 0,15 & 1,61 \\
\hline \multicolumn{6}{|c|}{ У \% до Lc } \\
\hline 1 cor & 70,16 & 0,25 & 72,59 & 0,43 & 4,86 \\
\hline $\mathrm{H}$ & 23,06 & 0,32 & 22,22 & 0,24 & 2,13 \\
\hline $\mathrm{h}$ & 7,22 & 0,06 & 6,69 & 0,08 & 5,08 \\
\hline $\mathrm{iH}$ & 9,76 & 0,13 & 9,19 & 0,16 & 2,77 \\
\hline $\mathrm{aD}$ & 44,42 & 0,23 & 47,21 & 0,24 & 8,38 \\
\hline $\mathrm{p} \mathrm{D}$ & 41,31 & 0,26 & 41,16 & 0,28 & 0,38 \\
\hline $\mathrm{aP}$ & 24,59 & 0,20 & 25,31 & 0,16 & 2,81 \\
\hline $\mathrm{a} \mathrm{V}$ & 48,39 & 0,38 & 48,34 & 0,13 & 0,13 \\
\hline a A & 69,67 & 0,55 & 69,95 & 0,27 & 0,47 \\
\hline $\mathrm{PV}$ & 24,38 & 0,25 & 22,88 & 0,25 & 4,29 \\
\hline $\mathrm{V} \mathrm{A}$ & 23,05 & 0,22 & 22,16 & 0,24 & 2,75 \\
\hline $1-\mathrm{D}$ & 13,50 & 0,13 & 12,56 & 0,11 & 5,55 \\
\hline $\mathrm{h}-\mathrm{D}$ & 12,93 & 0,09 & 12,33 & 0,15 & 3,36 \\
\hline $1-\mathrm{A}$ & 14,92 & 0,31 & 15,91 & 0,15 & 2,90 \\
\hline $\mathrm{h}-\mathrm{A}$ & 4,85 & 0,12 & 6,56 & 0,10 & 10,80 \\
\hline $1-\mathrm{P}$ & 15,08 & 0,20 & 15,79 & 0,12 & 3,05 \\
\hline $1-V$ & 10,12 & 0,16 & 9,63 & 0,11 & 2,58 \\
\hline $\mathrm{p}-1$ & 11,43 & 0,09 & 13,78 & 0,22 & 9,78 \\
\hline $1 \mathrm{c}$ & 26,06 & 0,41 & 25,31 & 0,16 & 1,69 \\
\hline \multicolumn{6}{|c|}{ У \% до lc } \\
\hline $\mathrm{ar}$ & 27,39 & 0,40 & 28,74 & 0,15 & 3,15 \\
\hline $\mathrm{do}$ & 21,41 & 0,45 & 23,77 & 0,24 & 4,66 \\
\hline $\mathrm{p} \mathrm{c}$ & 44,77 & 1,39 & 53,64 & 0,40 & 6,14 \\
\hline $\mathrm{h} \mathrm{c}$ & 61,69 & 1,19 & 75,68 & 0,37 & 11,25 \\
\hline I o & 17,09 & 0,25 & 17,70 & 0,45 & 1,18 \\
\hline
\end{tabular}

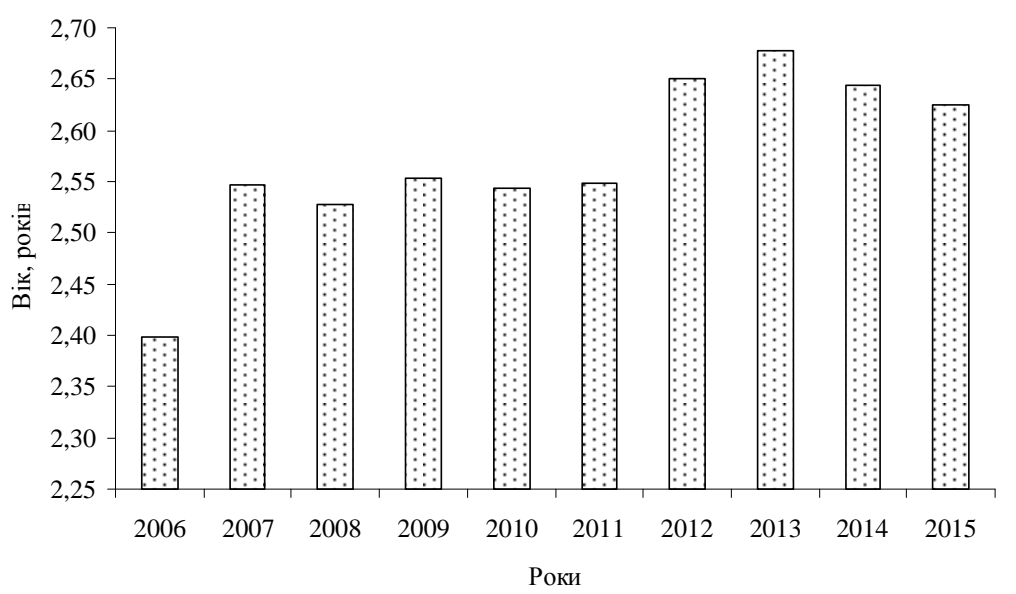

Рис. 1. Динаміка середнього виваженого віку стада пузанка Дніпровсько-Бузької гирлової системи

Представлена динаміка змін обумовлювалася розширенням вікового ряду за рахунок старших вікових груп. На початку розглянутого періоду до 94,3\% чисельності стада було представлено дворічками та трирічками. У послідуючі роки помічено збільшення чисельності чотирирічок (з 5,7 до 11,2\%) та п'ятирічок - до 6,4-6,8\% загальної чисельності стада (табл. 2).

102 ISSN 2078-2357. Наук. зап. Терноп. нац. пед. ун-ту. Сер. Біол., 2019, № 1 (75) 
Таблиия 2

Вікова структура пузанка Дніпровсько-Бузької гирлової системи, питома вага у загальній кількості, \%

\begin{tabular}{|c|c|c|c|c|c|}
\hline \multirow{2}{*}{ Роки } & \multicolumn{4}{|c|}{ Вік, років } & \multirow{2}{*}{ екз } \\
\hline & 2 & 3 & 4 & 5 & \\
\hline 2006 & 65,9 & 28,4 & 5,7 & - & 290 \\
\hline 2007 & 60,8 & 23,7 & 15,5 & - & 410 \\
\hline 2008 & 56,3 & 34,6 & 9,1 & - & 440 \\
\hline 2009 & 61,2 & 22,3 & 16,5 & - & 516 \\
\hline 2010 & 60,5 & 26,7 & 10,7 & 2,1 & 581 \\
\hline 2011 & 57,6 & 31,4 & 9,6 & 1,4 & 316 \\
\hline 2012 & 53,1 & 32,4 & 10,8 & 3,7 & 350 \\
\hline 2013 & 55,8 & 27,1 & 10,7 & 6,4 & 425 \\
\hline 2014 & 58,4 & 25,6 & 9,2 & 6,8 & 385 \\
\hline 2015 & 57,3 & 27,2 & 11,2 & 4,3 & 365 \\
\hline
\end{tabular}

Представлена інформація вказує на те, що частка поповнення (дворічки) поступово зменшувалася з 65,9 до 57,3\%, проте у трирічок була відносно стабільною. При цьому важливо наголосити, що в модальних групах статеве співвідношення було найбільш оптимальним (табл. 3).

Таблиия 3

Статева структура стада пузанка Дніпровсько-Бузької гирлової системи (осереднені дані 2006-2015рp., \%)

\begin{tabular}{|c|c|c|c|c|c|}
\hline \multirow{2}{*}{ Вік, років } & \multicolumn{2}{|c|}{ Самиці } & \multicolumn{2}{|c|}{ Самці } & \multirow{2}{*}{ Співвідношення } \\
& екз & $\%$ & ек3 & \% \\
\hline 2 & 1365 & 57,0 & 1029 & 43,0 & $1: 0,75$ \\
\hline 3 & 699 & 62,0 & 429 & 38,0 & $1: 0,61$ \\
\hline 4 & 347 & 75,9 & 110 & 24,1 & $1: 0,32$ \\
\hline 5 & 89 & 89,9 & 10 & 10,1 & $1: 0,11$ \\
\hline Загалом & 2500 & 61,3 & 1578 & 38,7 & $1: 0,63$ \\
\hline
\end{tabular}

3 наведених даних достатньо очевидним є те, що оптимальну чисельність пузанка підтримують переважно дві вікові групи - дворічки та трирічки, які забезпечують відтворювальну здатність стада в цілому.

Темп росту пузанка відрізнявся певною інтенсивністю. Лінійні розміри в залежності від віку змінювалися в межах від 10,82 $\pm 0,17$ см (lim=9,9-11,5 cм) у дворічок до 22,2 $\pm 0,14$ см (lim=21,8-22,7 см) у п'ятирічок. Темп росту маси тіла був більш інтенсивним, що залежало від статевої структури та характеру дозрівання плідників. Середня маса зростала від 14,2 $\pm 0,64$ г

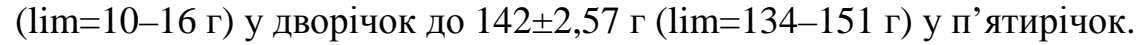

Мінливість характеристик росту пузанка знижується зі збільшенням віку. При цьому варіабельність довжини була набагато нижчою, ніж маси тіла, що обумовлювало динаміку вікових змін вгодованості (рис. 2).

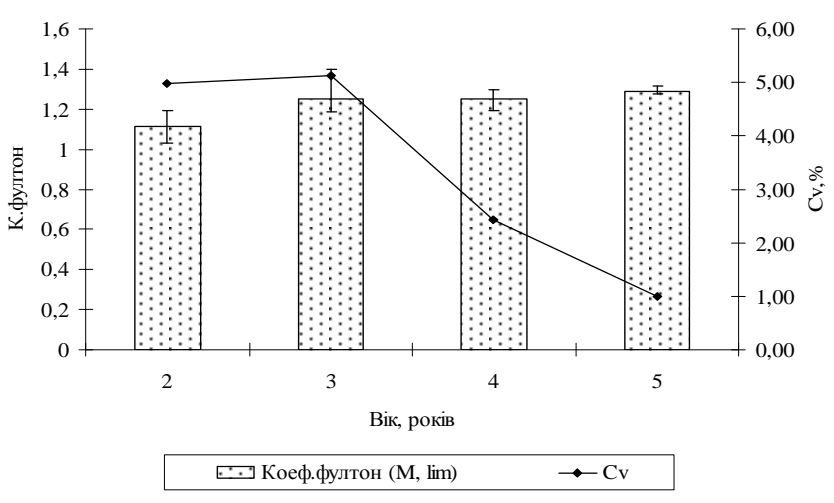

Рис. 2. Динаміка вікових змін вгодованості пузанка Дніпровсько-Бузької гирлової системи, осереднені дані за 2006-2015 pр. 
Представлена інформація рисунку 2 вказує на те, що абсолютні показники вгодованості за віковими групами є відносно однорідними, проте відмічається незначне їх зростання зі збільшенням віку від $1,11 \pm 0,02$ (lim=1,03-1,19) у дворічок до 1,29 $\pm 0,01$ (lim=1,26-1,31) у п’ятирічок.

\section{Висновки}

Аналіз головних біологічних характеристик пузанка, який мігрує до Дніпровсько-Бузької гирлової системи вказує на задовільний стан стада в цілому з позитивними тенденціями вікової структури. Проте відмічене останніми роками зростання частки старших вікових груп обумовлює впровадження певних заходів щодо оптимізації їх чисельності.

1. Екологічні трансформації річкових гідроекосистем та актуальні проблеми рибного господарства / І.М. Шерман, К.М. Гейна, С.В. Кутіщев, П.С. Кутіщев // Рибогосподарська наука України. — 2013. - № 4. - C. 5-16.

2. Световидов А.Н. Сельдевые (Clupeidae) // Фауна СССР. Рыбы. - М. — Л.: Изд-во АН СССР, 1952. -2, Вып. 1. — 331 с.

3. Залевский С.В. Биология и промысел пузанка Днепровско-Бугского лимана (Alosa caspia nordmanni Antipa) // Автореф.дис...канд.биол.наук. - Киев, 1955. - 15 с.

4. Залевский С.В. О морфоологических и биологических особенностях пузанка Днепровско-Бугского лимана // Зоол.журн. - Т. 32. - Вып. 8. - 1958. - С. 1195-1198.

5. Залевский С.В. О плодовитости пузанка Alosa caspia nordmanni Antipa // Вопр.ихтиологии, 1960. Вып.14. - С. 81-86.

6. Владимиров В.И. Условия размножения рыб в нижнем Днепре и Каховское гидростроительство. К.: Изд-во АН УССР, 1955. - 148 с.

7. Павлов П.Й. Оселедцеві роду Alosa північно-західної частини Чорного моря. - К.: Вид-во АН УРСР, 1959. - $252 \mathrm{c}$.

8. Павлов П.И. Современное состояние запасов промысловых рыб нижнего Днепра и ДнепровскоБугского лимана и их охрана. - Киев, 1964. Рукопись деп. в ВИНИТИ, №27-64 деп. - 268 с.

9. Щербуха А.Я. Морфологічні властивості пузанка Alosa caspia tanaika nation nordmanni Antipa 3 пониззя Південного Бугу // Біологія та морфологія риб та санітарно-біологічний режим прісних водойм України. - К.:Наукова думка, 1966. - С. 156-159.

10. Правдин И.Ф. Руководство по изучению рыб. - М.: Пищевая промышленность, $1966 .-375$ с.

11. Брюзгин В.Л. Методы изучения роста рыб по чешуе, костям и отолитам. - Киев: Наукова думка., $1969 .-187 \mathrm{c}$.

12. Чугунова Н.И. Руководство по изучению возраста и роста рыб. - М., - 1959. — 164 с.

13. Методика збору і обробки іхтіологічних і гідробіологічних матеріалів з метою визначення лімітів промислового вилучення риб з великих водосховищ і лиманів України. — К.: ІРГ УААН, 1998. — 47 с.

14. Плохинский Н.А. Алгоритмы биометрии. - М.: Изд-во МГУ, 1980. - 150с.

15. Аксютина 3.М. Элементы математической оценки результатов наблюдений в биологических и рыбохозяйственных исследованиях. - М.: Пищевая промышленность, 1968. —289 с.

\section{References}

1. Ekolohichni transformatsii richkovykh hidroekosystem ta aktual'ni problemy rybnoho hospodarstva / I.M. Sherman, K.M. Heyna, S.V. Kutishchev, P.S. Kutishchev // Rybohospodars'ka nauka Ukrainy. 2013. - No 4. - S. 5-16. (in Ukrainian).

2. Svetovidov A.N. Sel'devye (Clupeidae) // Fauna SSSR. Ryby. - M. - L.: Izd-vo AN SSSR, 1952. -2, Vyp. 1. - 331 s. (in Russian).

3. Zalevskiy S.V. Biologiia i promysel puzanka Dneprovsko-Bugskogo limana (Alosa caspia nordmanni Antipa) // Avtoref.dis...kand.biol.nauk. - Kiev, 1955. - 15 s. (in Russian).

4. Zalevskiy S.V. O morfoologicheskikh i biologicheskikh osobennostiakh puzanka Dneprovsko-Bugskogo limana // Zool.zhurn. - T. 32. - Vyp. 8. - 1958. - S. 1195-1198. (in Russian).

5. Zalevskiy S.V. O plodovitosti puzanka Alosa caspia nordmanni Antipa // Vopr.ikhtiologii, 1960. Vyp.14. - S. 81-86. (in Russian).

6. Vladimirov V.I. Usloviia razmnozheniia ryb v nizhnem Dnepre i Kakhovskoe gidrostroitel'stvo. — K.: Izdvo AN USSR, 1955. — 148 s. (in Russian).

7. Pavlov P.Y. Oseledtsevi rodu Alosa pivnichno-zakhidnoi chastyny Chornoho moria. - K.: Vyd-vo AN URSR, 1959. - 252 s. (in Ukrainian).

8. Pavlov P.I. Sovremennoe sostoianie zapasov promyslovykh ryb nizhnego Dnepra i Dneprovsko-Bugskogo limana i ikh okhrana. - Kiev, 1964. Rukopis' dep. v VINITI, No27-64 dep. — 268 s. (in Russian). 
9. Shcherbukha A.Ya. Morfolohichni vlastyvosti puzanka Alosa caspia tanaika nation nordmanni Antipa z ponyzzia Pivdennoho Buhu // Biolohiia ta morfolohiia ryb ta sanitarno-biolohichnyy rezhym prisnykh vodoym Ukrainy. - K.: Naukova dumka, 1966. - S. 156-159. (in Ukrainian).

10. Pravdin I.F. Rukovodstvo po izucheniiu ryb. - M.: Pishchevaia promyshlennost', 1966. —375 s. (in Russian).

11. Briuzgin V.L. Metody izucheniia rosta ryb po cheshue, kostiam i otolitam. — Kiev: Naukova dumka, 1969. - 187 s. (in Russian).

12. Chugunova N.I. Rukovodstvo po izucheniiu vozrasta i rosta ryb. - M., - 1959. - 164 s. (in Russian).

13. Metodyka zboru i obrobky ikhtiolohichnykh i hidrobiolohichnykh materialiv z metoiu vyznachennia limitiv promyslovoho vyluchennia ryb z velykykh vodoskhovyshch i lymaniv Ukrainy. — K.: IRH UAAN, 1998. - 47 s. (in Ukrainian).

14. Plokhinskiy N.A. Algoritmy biometrii. - M.: Izd-vo MGU, 1980. - 150s. (in Russian).

15. Aksiutina Z.M. Elementy matematicheskoy otsenki rezul'tatov nabliudeniy $\mathrm{v}$ biologicheskikh i rybokhoziaystvennykh issledovaniiakh. - M.: Pishchevaia promyshlennost', 1968. - 289 s. (in Russian).

\section{K.N. Geina}

Institute of Fisheries NAAS Ukraine

\section{MORPHO-BIOLOGICAL PUSA CHARACTERISTICS OF THE DNEPR-BUG STOCK SYSTEM}

The article provides information on the current biological status of the commercial herds of the Puzanka (Alosa caspia tanaica, G., 1901) Dnieper-Bug estuary system. Meristic, plastic signs are analyzed, sexual dimorphism and structural characteristics of the herd are determined.

Key words: Dnieper-Bug estuary system, puzanov, plastic, meristic features, herd structure

Надійшла 23.01.2019.

УДК: $556.53:(597.551 .2+597.556 .33+597.552 .1): 546.302$

doi:10.25128/2078-2357.19.1.14

\section{Б.З. ЛЯВРІН, В.О. ХОМЕНЧУК, В.З. КУРАНТ}

Тернопільський національний педагогічний університет імені Володимира Гнатюка вул. Максима Кривоноса, 2, Тернопіль, 46027

e-mail: bohdan.lyavrin@gmail.com

\section{ВМІСТ ФЕРУМУ, МАНГАНУ, КОБАЛЬТУ, ЦИНКУ ТА КУПРУМУ В ОРГАНІЗМІ РИБ ІЗ РІЧОК СЕРЕТ, СТРИПА І ЗОЛОТА ЛИПА}

У роботі досліджено вміст окремих металів у тканинах коропа, карася, окуня та щуки із малих річок Західного Поділля. Показано, що для різних металів існують специфічні закономірності накопичення в різних тканинах організму. Проте, загальними тенденціями, які визначають клітинні трансформації у риб, є: тканинно-специфічна локалізація клітин, що повязано $з$ їх морфологією, хімічним складом та мембранною активністю; хімічна активність іону металу, особливо комплексоутворююча здатність із білками та низькомолекулярними метаболітами; концентрація іонів, яка впливає на загальний іонний гомеостаз в організмі. Відмічено також міжвидові відмінності тканин риб у накопиченні досліджених металів.

Ключові слова:, Ферум, Манган, Кобальт, Цинк, Купрум, акумулювання, риби, малі річки

Проблема використання і ресурсозбереження прісних вод і водних екосистем $є$ однією 3 найбільш актуальних в умовах інтенсивного антропічного навантаження на довкілля. Спостереження останніх років свідчать про те, що гідрохімічний режим прісних водойм, який визначає якість води в них, тісно пов'язаний з концентрацією іонів металів [7].

Важкі метали, які надходять у довкілля із антропогенних джерел забруднення, суттєво впливають на стан водних екосистем. Це проявляється у збільшенні їх вмісту в воді, донних 